\title{
WICKED WEBS: BUSINESS PARTNER NETWORKS AND SILENCE
}

\section{REDES PERVERSAS: AS REDES SOCIAIS DE PARCEIROS E O SILÊNCIO}

\section{Recebido em 26.05.2019 Aprovado em 26.08.2019 Avaliado pelo sistema double blind review

Ana Carla Bon

anacarla.bon@hotmail.com

IAG/Pontifícia Universidade Católica do Rio de Janeiro - Rio de Janeiro/RJ, Brasil

https://orcid.org/0000-0002-8108-2700

\section{Sylvia Therezinha de Almeida Moraes}

sylviatam@prof.iag.puc-rio.br

IAG/Pontifícia Universidade Católica do Rio de Janeiro - Rio de Janeiro/RJ, Brasil

https://orcid.org/0000-0002-8409-6884

\section{Jorge Ferreira da Silva}

shopshop@iag.puc-rio.br

IAG/Pontifícia Universidade Católica do Rio de Janeiro - Rio de Janeiro/RJ, Brasil

https://orcid.org/0000-0002-0021-8398

\begin{abstract}
This study suggests that researches should look beyond the more often visible positive effects of alliances and social networks, to investigate how wicked webs can develop an efficient corrupted system. Bridging social network and alliances' areas of research, this theoretical review proposes three pillars to understand and prevent corruption: focus in the internal networks of the firm which decide for corruption, the partners networks and how they are connected to the firm, and the mechanism through which social network prevent people from talking about ethical issues, let alone blow the whistle, creating a snowball effect where corruption is acceptable.
\end{abstract}

Keywords: Corruption. Partners. Alliances. Silence. Social Networks.

\section{Resumo em português}

Este artigo sugere que além dos efeitos positivos visíveis de alianças e redes sociais, as pesquisas devem também investigar como redes perversas de parceiros podem desenvolver um sistema eficiente de corrupção. Baseada nas pesquisas de redes sociais e de alianças, esta revisão teórica propõe três pilares para entender e prevenir a corrupção: foco nas redes internas da empresa que decidem por corrupção, as redes de parceiros e como eles estão conectados à empresa e o mecanismo através do qual a rede social constrange o posicionamento aberto sobre questões éticas criando um efeito bola de neve onde a corrupção é aceitável.

Palavras-chave: Corrupção. Parceiros. Alianças. Silêncio. Redes Sociais. 


\section{Introduction}

One of the most insidious forms of unethical behavior and illegality is corruption, which has become a serious problem, especially in poor and emerging markets, and impacting the achievement of sustainable development goals. Corruption affects investments and economic growth, exacerbates inequality ( $\mathrm{Li}, \mathrm{Xu}$, \& Zou, 2000; Mauro, 1995), drains financial resources from healthcare and education (Mauro, 1998), exerts pressure on environmental controls and policies (Esty \& Porter, 2002), supports oligarchic control (Fogel, 2006), and increases risks and uncertainty (Getz \& Volkema, 2001). As Baughn, Bodie, Buchaman and Bixby (2010) argued, the level of bribery can be seen as a function of both supply (payers, corporations) and demand (recipients, e.g. government), and individual firms can, in fact, benefit from it (Galang, 2012; Melo, Sampaio, \& Oliveira, 2015). Therefore, it is fundamental to prevent corruption in order to advance the implementation of sustainable development goals.

In Brazil the situation is endemic, as reflected by everyday headlines, such as the eye-opening cases involving PETROBRAS and Odebrecht. A KPMG survey of 500 executives at top Brazilian firms revealed that an astonishing $62 \%$ of respondents admitted that their companies might be engaged in corruption, and an even higher percentage, $85 \%$, believed that their competitors might also be willfully engaged in such behavior. Moreover, in 2013 PWC surveyed 132 firms in Brazil and found that 27\% admitted to having engaged in some type of unethical behavior, for example, bribery, fraud, and/or asset deviation (Torres, 2014). However, this phenomenon is not restricted solely to Brazil or Brazilian companies. As Ashforth, Gioia, Robinson and Trevino (2008, 670) summarized: "Corruption, it seems, is everywhere."

A number of researchers have investigated the causes of corruption and ways to prevent it. Based on an extensive review of the literature on corruption covering the period 1996-2008, Galang (2012) proposed a framework on how firms use different strategic approaches to deal with government corruption. Corruption in Latin America was also reviewed by Nicholls-Nixon, Castilla and Garcia (2011) (e.g., Beekun, Stedham, \& Yamamura, 2003; Husted, 2002; Melé, Debeljuh, \& Arruda, 2006).

Scholars have taken different approaches, such as the macro perspective, analyzing the impact of country-level factors - economic, social, legal and cultural - on corruption (Chen, Yasar, \& Rejeus, 2008; Ferreira, Carreira, Li, \& Serra, 2016; López \& Santos, 2014; Martin, Cullen, Johnson, \& Parboteeah, 2007; Mc Carthy, \& Puffer, 2008; Svensson, 2003). Moreover, institutional factors such as political, legal, economic, and educational systems are at the same time antecedents and effects of corruption, creating a feedback loop which weaken national institutions (Judge, McNatt, \& Xu, 2011). Others have analyzed the option for a strategy that includes corruption (e.g., Rodriguez, Uhlenbruck, \& Eden, 2005). Moreover, relevant studies about how corporations may prevent and resist corruption have also been published (Anand, Ashforth, \& Joshi, 2004; Beenen \& Pinto, 2009).

The fact is that so far research has shown that different factors - individual, organizational, situational can contribute to unethical situations and corruption (Jackson, Wood, \& Zboja, 2013; Kish-Gephardt, Harrison, \& Trevino, 2010; O’Fallon \& Butterfield, 2005; Pendse, 2012). One situational factor that can serve as a means for corruption is the social network. As Greve, Palmer and Pozner (2010, p. 68) discussed "many cases of organizational misconduct are collective efforts intentionally orchestrated by a number of interconnected individuals". Indeed, certain scholars have called attention to understanding which social network might be most likely to promote corruption and fraud (Bon, Volkema, \& Silva, 2017; Brass, Butterfield, \& Skaags, 1998; Nielsen, 2003; Huang \& Rice, 2012). Corrupt individuals and/or organizations can develop alliance networks, using their social capital (power, influence, information) to “outsource” bribes (Spencer \& Gomez, 2011) and create cartels (Bertand \& Lumineau, 2016).

On the other hand, non-corrupted individuals may feel the need to remain silent in light of such deviation in firms in order not to lose their own social capital (Milliken, Morrison, \& Hewlin, 2003). But keeping quiet fosters a snowball effect where corruption is acceptable. It also increases the perceived behavioral 
tolerance of future acts of corruption, thereby creating an incentive for further unethical actions (Chang \& Lail, 2002; De Maria, 2006; Muehlheusser \& Roider, 2008).

Although social network research is well developed in areas such as career, firm performance, and alliances, it has been overlooked for analyzing corruption and unethical acts in general. In Brazil, research on corruption is just getting started, although the subject has recently attracted the attention of a few scholars. Some studies found negative effects of corruption such as devaluation on the Brazilian Stock Markets of firms engaged in corruption (Miari, Mesquita \& Pardini, 2015; Padula \& Albuquerque, 2018) and public administration inefficiency in state-owned enterprises or in direct administration (Junior Lopes et al., 2018; Sodré \& Alves, 2010). On the other side, "positive" effects (reduction of burocracy's impact to create the business) were also found in small-business and entrepreneurship results (Borini \& Grini, 2009; Melo, Sampaio \& Oliveira, 2014). Moreover, cultural aspects were related to corruption such as the Brazilian jeitinho (Torres, Alfinito, Galvão, Tse, 2015) or can explain avoidance to whistleblowing (Behrens, 2015). However, very few studies investigated corruption using the network lens to identify corrupt actors (Bon, Volkema, Silva, 2017; Ribeiro, Alves, Martins and Leniz, 2018) or personal relationships and individual factors which can impact whistleblowing (Sampaio, 2015; Santos, Guevara \&Amorim, 2013).

This study draws on social network theories and research to understand and prevent corruption based on three pillars: first, it is important to focus on the internal networks of the firm (the groups within the firm) that support a decision to commit unethical acts; second, it is fundamental to understand the wicked webs that alliance networks can build, and how these are connected with the firm (the inter-firm connection); and lastly, the social network can be a valuable tool to understand why people do not even want to talk about ethical issues, let alone blow the whistle (Flynn and Wiltermuth, 2010), considering that there are mechanisms available for doing so. The conclusion of this study includes a discussion of corruption prevention and suggestions for future research.

\section{Theoretical Review}

\section{Partner Networks: The outsourcing of corruption}

Rabl and Kuhlmann (2008) contributed to the definition of corruption, reviewing the many dimensions that the literature presents. They found that corruption is characterized by: 1) an exchange between partners by mutual agreement; 2) a violation of norms; 3) an abuse of power; 4) an absence of direct victims; and 5) secrecy of their exchange relationship. However, it is important to realize that corruption is an unethical as well as an illegal act, and although legal enforcement does play a role (Ajzen, 1991), it is often limited due to corruption's characteristics of secrecy and absence of direct victims.

Pinto, Leana and Pil (2008) proposed a classification of corruption in organizations, defining two dimensions: 1) the party or parties that receive the benefits of the corruption - the organization or an individual; and 2) the corrupt act being engaged in by one or more individuals. The authors then defined a new type of corruption at the organizational level - the organization of corrupt individuals (OCI) - and differentiated it from the corrupt organization (CO) concept. Regarding the primary beneficiary, they stated that, even if individuals do benefit financially - for example, winning a contract by means of a corrupt act (e.g. through bonuses or promotions for achieving certain objectives) - the organization is still the primary beneficiary. The authors argued that corruption which benefits only individuals - for example, stealing or over-reporting of expenses - is usually perpetrated by the individual. On the other hand, corruption that benefits an organization, $\mathrm{CO}$, is corrupt behavior on behalf of the organization itself.

As defined by Gulati (1998), an alliance is any cooperative effort between two or more independent organizations to develop, manufacture, or sell products and services. Inter-organizational relationships are recognized as an important source of competitive advantage and superior performance, so the 
configuration and development of alliance networks is a key strategic issue (Gulati, Nohria, \& Zaaher, 2000; Hoffman, 2007). Nonetheless, alliance networks also have a dark side, which includes masking a corrupted system (Ayios, Jeurissen, Manning, \& Spense, 2014; Melé, 2009). And most alliance types can be used for such a purpose: from an agent who merely receives a fee for closing a contract or for acting as a lobbyist, to the most complex joint-venture organization.

As Granovetter (1985) explained, it is important to understand that economic action is not independent of the social relationships surrounding an economic actor. The individuals are, in the end, the ones who invest in relationships in order to gain access to resources, that is, actors can utilize their social capital for a strategic purpose. Brass, Butterfield and Skaggs (1998) were pioneers in attempting to understand which social network conditions would be most likely to result in unethical actions. They presented a model under which an unethical decision may be the result of the interplay of individual, organizational and issue-related factors, but it may also involve individual social networks. They argued that the types and the structure of relationships can provide constraints against, or opportunities for, unethical behavior. Accordingly, Nielsen (2003) argued that a corrupt system is an integrated network and he suggested that to reform a corruption subsystem, it would be necessary to address the network rather than just the individual.

One aspect that has been debated in social network literature is the need to apply multilevel analysis. As Moliterno and Mahony (2011) argued, the network theory should use multilevel scope and perspective inasmuch as organizations are multilevel systems of relationships, applying the concepts of nested networks. Therefore, there are two ways a network may support a corrupted environment: one is internal to the firm (individuals who decide on a market strategy based on corrupt alliances); the other is external (the partner per se) to the firm, linked to it by a limited number of brokers (individuals whose connections are not connected with each other).

Burt $(2005,141)$ discussed the "brokerage-closure tension," regarding the polemic in the literature about which network entails the best performance, (and in this case "best performance" means developing an efficient corrupted system that is more difficult to uncover), clarifying that they are not antagonistic, but complementary: "performance is highest for closure within a group combined with brokerage beyond the group." Therefore, individuals strongly connected with one another (that is, in closure) in a corruption network inside the firm will have the advantage of being aligned and effectively executing the strategy of outsourcing bribery through brokers, who will be responsible for connecting with the firm's partners.

In fact, network closure may function as a fortress for protecting the unethical individuals in a firm from the risk of being discovered and for ensuring trust among the members of the network, keeping secrecy as a commitment among its members (Brass et al., 1998). It is interesting how the words of Poldony and Baron (1997, p. 676) about network closure are apropos not only for ethical acts, but also for corruption, arguing that the type of network "...is often a precondition for: (1) internalizing a clear and consistent set of expectations and values in order to be effective in one's role; and (2) developing the trust and support from others that is necessary to access certain crucial resources (...) and to implement strategic initiatives."

On the other hand, Morselli and Roy (2008), merging criminal-script analysis with social network analysis based on Burt's (2005) structure hole theory, found that brokers are fundamental for maintaining flexibility in criminal activities. Upon studying criminal literature the authors noted that brokerage entails benefits for both criminal and legitimate enterprises. Additionally, they analyzed brokerage between subgroups within a network and found that the removal of brokers should have a negative impact on crime perpetration.

Accordingly, Klerks (2001) argued that social network analysis is valuable for studying criminal organization because it allows to identify certain positions and roles that would not otherwise be detected. Klerks refers to such individuals as "criminal contact brokers" - those who innovate and adapt 
quickly to avoid legal intervention. In the same vein, Van Meter (2001) argued that the criminal network structure is what supports the informal, flexible and opportunistic operations, in which few actors mobilize a large number of other parties who share the profits of the actions; that is, a few brokers provide access to the required social capital.

Rodriguez, Uhlenbruck and Eden (2005) argued that corruption affects the strategic choice of a multinational's mode of entry and creates an incentive for the development of social networks that can be sources of external legitimacy. To penetrate the social network in a foreign country, the company will choose a partner (for example, in a joint-venture model) who is willing to engage in bribery. Along the same lines, in a study of the pressures that MNE subsidiaries face to engage in bribery, Spencer and Gomez (2011) found that firms with local partners or local partial ownership face greater pressure to engage in corruption than firms without these structures. They gave two possible explanations for this. The first one is that corrupt officials might seek alternative access points (the partners) to accept bribery requests instead of approaching MNE subsidiaries directly. The second is that the MNE subsidiary does decide to engage in corruption, but does so through its partners: it "outsources" the "need to bribe," so that the act becomes less apparent to stakeholders and serves as a means for local management to deny that such practices exist. Thus, the inclusion of a partner mediating the bribery provides not only the "means" for the action (PENDSE, 2012), but also creates more complex transactions, making control and auditing difficult (Cohen et al., 2010).

Ribeiro et al. (2018) analyzed sixty-five political corruption scandals in Brazil over a period of 27 years, and found that corruption was based in small networks (no more than 8 people), and there was a tight link between scandals, as well as it was possible to identify the individuals who were central to the network. Therefore, they proposed that, focusing on the dynamics structure of the network, it would be possible to predict corrupted actors in future scandals.

Bon, Volkema and Silva (2017), analyzing the networks of individuals within firms, confirmed that the risk of unethical acts increases for individuals in more closed networks (lower centrality), probably due to the need to have strong control of the situation and guarantee secrecy. However, following other researchers (e.g., Brass et al., 1998; Kilduff \& Krackhardt, 2008) who posited that the structure of the social network is not enough to predict results (that is, it is necessary to consider the individual who is in the network), they found that gender and self-monitoring personality affect the pattern of the social network and the ethical intention of the individual. High self-monitors in very closed network are the ones who had higher unethical decision-making, including corruption through partners. Moreover, they suggested that women could be more ethical than men in high moral issues level (Jones, 1999), such as corruption.

On the other hand, some scholars have discussed the cultural excuse to perpetuate corruption and bribery. Huang and Rice (2012) studied the role of inter-firm networking in widespread bribery and corruption in China, and analyzed how guanxi, defined as interpersonal relationships and connections (Su \& Littlefield, 2001), used by business and associated with institutional weaknesses, leads to increased corruption. Other studies have discussed the use ("or abuse") of guanxi-based networks and the deterioration of business ethics in China (Bedford, 2011; Su, Sirgy, \& Littlefield, 2003).

Similarly, considering the importance of personal networks in business in Russia, McCarthy and Puffer (2008) examined the cultural aspect of the blat (personal favor). They used the definition of Ledenova (1998, p. 37) to blat as "....an exchange of favors of access in conditions of shortages and a state system of privileges... Blat provides access to public resources through personal channels." The authors noted that in many circumstances there is no clear demarcation between blat and corruption and that the "dark side" of the economy is huge in Russia. McCarthy, Puffer, Dunlap and Jaeger (2012, p. 27) argued that these cultural relationships stemming from favors (defined as "an exchange of outcomes, between individuals, typically utilizing one's connections, that is, based on a commonly understood cultural tradition...') are present in all the BRIC countries: the jeitinho in Brazil, the blat in Russia, the jaan-pehchaan in India and the guanxi in 
China. Accordingly, Torres, Alfinito, Galvão \& Tse (2015) also found that Brazilian jeitinho was related to corruption.

Omission in general can perpetuate this situation since the fraud or unethical behavior of one individual can result in benefits for another or all individuals. Alternatively, as the next section will show, silence in order to avoid a loss of social capital and reputation can underlie a "wall of silence" within the organization, thereby creating an incentive for further unethical actions.

\section{Unethical silence in order to protect social capital}

Communication is a fundamental process in human interaction and relationship development; hence, communication is part of the development of social networks. As Blau (1986) explained, social relations and transactions involve communication, and the form of social communication shapes an individual's opinions. However, in order to maintain relationships, individuals may decide not to voice their opinions if doing so might create problems for the maintenance of the relationship. Or as Flynn and Wiltermuth $(2010,1079)$ pointed out, the problem can be even worse, in that members of organizations tend to avoid moral discourse, preferring to restrict the subject matter to less sensitive topics. In other words, the "discussion of morality seems almost taboo" inside organizations.

De Maria (2006) argued that secrecy and organizational silence may exponentially increase the incidence of unethical behavior and corruption in ways that are still not understood. He noted that, among other implications, silence can foster the continuance of illegal practices (Beamish 2000) and at the same time preserve power differences (Bowen $\&$ Blackmon, 2003). In addition, he wondered if concerns in relation to one's career might also be a possible reason for silence.

Bird (1996) argued that although most business people do have moral convictions, they tend not to voice them. He also posited that one of the critical issues of moral silence is that it is self-reinforcing, and that similar psychological impulses occur when individuals lie: if they have been morally mute and if negative outcomes have not been discernible, they may consider it acceptable to stay silent. Furthermore, they may feel that it is necessary to cover up their silence with further silence in order to avoid being accused of awareness and failing to speak up.

Milliken, Morrison and Hewlin (2003) found that one of the most frequent reasons for silence in business is the fear of being viewed negatively (as a "troublemaker") and causing harm to valuable relationships. Assuming that individuals have relied on informal relationships to obtain information to do their jobs, such harm might affect their job and/or career. The authors suggested that perceived implications of a negative image can lead to a loss of trust, followed by social rejection and weakened social capital. They also proposed a model for choosing to remain silent based on three factors: individual, organizational, and relational, i.e., one's relationship with one's supervisor.

Muehlheusser and Roider (2008) analyzed the "wall of silence" phenomenon - honest employees that dislike unethical behaviors by other employees, but fail to voice their concerns to authorities. They argued that the importance of benefits that actors receive when cooperating with each other is a factor that influences keeping silent. In general, potential whistleblowers worry about reputational repercussions, which include the risk of being ostracized by the group, and the consequent loss of benefits as a group member, or problems when looking for a new career position. The problem with a group is that a decision to blow the whistle can also include information about an honest team member (for instance a member who witnessed the misconduct but remained silent). The authors developed a wall of silence model based on reputational concerns that indicates a feedback loop in the wall of silence, thereby functioning as an incentive for misbehavior and creating an equilibrium phenomenon. Viewing the wall of silence as a social norm, the model offers an explanation as to why some actors follow the behavioral rules despite their preference for other behaviors. 
Accordingly, Sampaio (2013) suggested that, in Brazil, cultural characteristics such as conflict aversion or predominance of interpersonal relationships in professional relations, may create fear to break personal ties between employees and their superiors or even fear of retaliation with social sanctions as managers from Brazilian organizations could consider whistleblowing as taboo or deviant behavior. Moreover, Santos et al. (2013) found, that women were less related to corruption - in line with other researches (e.g. Bon et al., 2017), but at the same time have less propensity to report unethical acts. Impressive also are the findings of Behrens (2015) who suggested cultural aspects can even bring drawbacks (unethical use of) whistleblowing such as maligning other professionals.

In his theory of social capital and action, Lin (2001) argued that the primary motive for an individual action is the maintenance of valued resources, followed by an action to gain additional resources. He explained that reputation and group solidarity - rational bases for social exchange - are sources of social capital. Lin (2001) defined individual reputation as a function of recognitions (social credits or social debts) received by an individual in a social group, while group reputation is a function of the sum of each individual reputation and the reputation of the group itself. Identification with a reputable group also enhances an individual's own reputation. This cyclical process supports an individual having an interest in maintaining group identification and solidarity.

Accordingly, Blau (1986) explained that an individual who is ostracized (lost reputation) by his or her group is penalized with a loss of social companionship and reward, and he or she is under significant pressure to find social acceptance, modify his or her behavior, or find another social group that accepts such behavior. The rationality in the process of social exchange -the calculation and choices of gains and losses - means that these choices are based on self-interest: collective interest enters the equation only when it is part of self-interest (Lin, 2001). As the meta-analysis of Kish-Gephart et al. (2010) suggested, self-interest, self-gain, and self-preservation may be some one of the common factors among the individual characteristics analyzed that leads to unethical behavior.

Furthermore, there is extensive social capital research (e.g. Seibert, Kraimer, \& Liden, 2001; Lin \& Erickson, 2008) that correlates the mobilization of social capital, formally or informally, to job information, achievement in the market, career, and success. Thus if an individual's act of exposing a corrupt act might cause loss in his or her social capital (information, influence, power), he or she may prefer to remain silent.

Knoll and Van Dick (2012) found that the intent to seek employment elsewhere is positively related to all forms of silence. Since career opportunities go beyond the current borders of the organization, a worker might not be looking to his or her sub-network of relationships inside the company, but to others outside it, whether professional (such as customers, partners, head-hunters or competitors) or personal (such as families and friends). In other words an individual may prefer to remain silent rather than blow the whistle on a perceived wrongdoing in a company in order to protect his or her safety, reputation (i.e., not be labeled a troublemaker) and career both within and outside the company.

Therefore, the connection between reputation and social capital explained by Lin (2001) gives support to the findings of Milliken et al. (2003) and Muehlheusser and Roider (2008) that an employee might keep silent about misbehavior in order to protect his or her reputation (as well as the whole group), and indirectly to protect his or her social capital. Chang and Lai (2002) modeled organization corruption as social interaction and discussed the "snowballing character of social norms." They explained that breaking a norm depends not only on individual sensitivity, but also on the number of people who follow the norms. Keeping silent to protect social capital fosters a snowball effect where corruption is acceptable and it increases the perceived behavioral tolerance of future acts of corruption. 


\section{Discussion}

This study proposed that researches should look beyond the more often visible positive effects of alliances and social networks, to investigate how wicked webs support the outsourcing of bribery and other corruption in general. Bridging social network and alliances' areas of research, with focus on the scarce literature of the "dark side", and answering the claim for more multi-level research, this study suggested that connected and nested social networks (inside and outside the firm) have to be investigated using Burt's (2005) brokerage-closure best performance concept. Moreover, it also explored how an endemic corruption can arise as a consequence of silence to protect social networks and social capital.

In summary, in a social network among partners, corrupt actions can be engaged in, for a number of reasons. These include: 1) to reduce the risk of being discovered - by complicating auditing control (Cohen et al., 2010), and reducing transparency to stakeholders, as well as functioning as an external legitimacy (Spencer \& Gomes, 2011); 2) to legitimize bribery as a social-cultural factor - local partners can exploit the Chinese guanxi or the Brazilian jeitinho, in the case of international firms, using these factors as an excuse to legitimatize their "need to bribe" (McCarthy \& Pfuffer, 2008; Huang \& Rice, 2012; Torres et al., 2015); and 3) to use trust and secrecy as a way to facilitate coordination and action while keeping the agreement secret (Bertrand \& Lunimeau, 2016; Brass eta al., 1998; Greve, Palmer \& Pozner, 2010). Finally, a snowball of corruption can be created through silence. Ethical individuals in corporations (the ones who do not agree/support corruption) can keep silence in order not to be regarded as troublemaker in their social network that support their career (Muehlheusser \& Roider, 2008; Sampaio, 2013).

\section{Corruption prevention}

Considering the potential risk of corruption damaging a company's reputation and society in general, corporations should take effective initiatives to insist that their business must have ethical underpinnings and that corruption must be regarded with "zero tolerance." However, although corruption is a highly sensitive moral issue, some studies have found that individuals can neutralize the moral issue by justifying an unethical pro-organizational behavior because it benefits the organization and/or its members, thus viewing their act as justified and themselves as not corrupt (Anand et al., 2004; Umphress, \& Bingham, 2011; Wiltermuth, 2011). Management should also be aware of this reinforcing trend in the development of networking, building a market of contacts. The risk is that by itself the net is becoming more important than "work," thus reflecting the unfortunate truth of the expression that "who you know is more important than what you know."

Therefore, network analysis can be a support to corruption prevention (Ribeiro et al., 2018). Corporations should be concerned about densely closed networks which are relatively isolated from the rest of the whole group within the firm, and at the same time maintain individuals who function as brokers, connecting their network to others firms (Brass et al., 1998; Greve, Palmer, \& Pozner, 2010). Tightly closed internal social networks could be broken and/or controlled by means of matrix organizations and more mobility between functions, avoiding groups connected as "honor among thieves" (Bon et al., 2017; Brass et al. 1998). However, gender differences in networking are fundamental to be analyzed as some studies have concluded that men and women build different patterns of networks: women have much more closed networks than men (Ibarra, 1997; Burt, 1998), but at the same time some studies found evidence that women engage less in bribery (Tuliao \& Chen, 2017).

One measure that some corporations have already adopted to prevent corruption is the role of the "Ethics and Compliance Officer" (E\&C), tasked with contributing to the prevention of unethical and illegal acts by developing ethical conduct and culture in organizations. The role is relatively new (see Weber \& Wasieleski, 2013 for a historical review) and is a mix of integrity-based - the ethics side - and rule-based - the compliance side (Coffey, 2014) behaviors. Scholars have discussed the complexity of the 
role of E\&C practitioners and they suggest a framework that includes personal, organizational and situational factors (Adobor, 2006; Colle, \& Werhane, 2008; Berenbein, 2010).

It is worth noting that the ethics officer is part of an ethics program that usually includes some or all of the following: a formal ethics code, an ethics committee, an ethics report line, an ethics officer, ethics training programs, and disciplinary procedures (Weaver, Trevino, \& Chochran, 1999). Some empirical research has shown that firms that have ethics programs and training are more willing to have their employees adhere to ethical behavior (e.g. Hauser, 2018; Kaptein, 2015).

Therefore, all such efforts should be applied to the whole network of the firm, including all alliance partners (business channels in general such as agents, VARs, distributors, and joint-ventures). However, this compliance throughout the whole chain is not without risk because the firm's reputation can be damaged by an unethical and/or illegal act by just one of the partners (Berenbein \& Walker, 2008). In addition, some scholars propose the repositioning of the ethics officer's role in relation to reporting to management since the position can pose a conflict of interest that can affect independence and objectivity (Hoffman, 2010; Hoffman, Neill \& Stovall, 2008).

Others discuss how these programs are still vulnerable (Weber \& Wasieleski, 2013) and suggest that corporations must move beyond compliance towards an ethics of integrity by breaking the culture of silence (e.g. Verhezen, 2010). Breaking the silence can be achieved by leadership openly expressing ethical views and, more importantly, by "walking the talk," but also by providing incentives and guarantees of protection for whistleblowing (including the whistleblower's social capital). Indeed, many companies still do not have any efficient and trustworthy channel for whistleblowing.

\section{Limitations and Future Research}

As in other researches, this study has some limitations. First it is not an exhaustive review of "the dark side" of social capital, although it has looked to different perspectives: studies that used social network theories and studies that investigated alliances, but using relationships as a generic term. Moreover, it has drawn mostly on Burt's structural hole theory (1992, 2005) and Coleman's (1990) network closure theory. Future research might profitably obtain additional insights by applying different social capital perspectives and theories, as well as multi-level approach (e.g, Bizzi, 2013). For example, the "brokerageclosure" combined effect should be further explored, analyzing the structure of network of individuals engaged in misconduct within the firm and the connection of a broker of this network to the outside.

Another important line of research could be to apply social capital theories which analyze not only the structure, but also the content of the network - as Lin's (1998) theory of social resource. In fact, Bertrand and Lumineau (2016) analyzing the effects of diversity between interconnected firms on the longevity of cartels, found that difference of age-based (which means diversity of information) and values among their members, as well as hierarchical organization, did predict cartel's longevity. It can also be important to use a macro perspective, such as Bourdieu's (1986) classical discussion of forms of capital - economic, social and cultural - and how they interact (e.g. Lizardo, 2009), or Putman's (2001) theory to explore the macro-micro connection.

Moreover, research could be enriched by applying more individual variables, including gender. Personality traits can affect both silence and the creation and effective use of social networks and therefore social capital (Bon et al., 2017, Kilduff \& Krackhardt, 2008; Tuliao \& Chen, 2017).Finally, cultural values can also impact the propensity to remain silent (Chelminski \& Coulter, 2007; Sampaio, 2015), affecting ethical discourse and whistleblowing. Whistleblowing can be seen as inappropriate in countries with high levels of collectivism, power distance and uncertainty avoidance (Hofstede, 1980), and therefore, corruption prevention can be better achieved if emphasized as a violation of group-based ideals for behavior. In fact, as corruption is context specific, many anticorruption strategies cannot be 
transferred automatically from one country to another (Behrens, 2013; Husted, 2002; Nicholls-Nixon et al., 2011).

\section{Final Comments}

Corruption is an economic and social disaster to any society. However, it persists since it can entail many benefits both at the individual and corporate level: reinforcement of power and promotions within the corporation; bonuses linked to direct (individual) and indirect (overall company results) performance; maintenance of the company's growth, hence protecting current employees; achievement of financial performance promised to shareholders, which directly impacts employees' stock options. Consequently, the situational pressures can outweigh the harm to society in general because of the benefits and rewards to those closer to the actor and the firm, thereby minimizing the moral intensity of using corruption. Legal and ethical forces must counter attack the problem neutralizing corruption.

This study offered social network lens to understand the factors that could facilitate or hinder corruption. It adds to previous research in the area of unethical decision and alliances by showing how the interaction of social network, individual factors and culture could be related to corruption. Last but not least, this paper adds to recent calls for management research to contribute to rethink governance in organizations in light of tackling the "grand challenges" of Sustainable Development Goals (George et al., 2016, p. 1880; Tihany, Graffin \& George, 2014). We hope this study contributes somehow to hamper the wicked webs in our society.

\section{References}

Adobor, H. (2006). Exploring the role of performance of corporate ethics officers. Journal of Business Ethics, 69, 57-75. doi:10.1007/s10551-006-9068-7

Ajzen, I. (1991). The theory of planned behavior. Organizational Behavior and Human Decision Process, 50,179-211. doi: 10.1016/0749-5978(91)90020-T

Anand, V., Ashforth, B. E., \& Joshi, M. (2004). Business as Usual: the acceptance and perpetuation of corruption in organizations. Academy Management Executive, 42, 426- 435. doi: 10.5465/AME.2004.13837437

Ashforth, B. E., Gioia, D. A., Robinson, S. L., \& Trevino, L. K. (2008). Re-viewing organizational corruption. Academy of Management Review, 23, 670-684. doi:10.5465/AMR.2008.32465714

Ayios, A., Jeurissen, R., Manning, P., \& Spence, L. J. (2014). Social capital: A review from an ethics perspective. Business Ethics: A European Review, 23, 108-124. doi: 10.1111/beer.12040

Baughn, C., Bodie, N. L., Buchanan, M. A., \& Bixby, M. B. (2010). Bribery in the international transactions. Journal of Business Ethics, 92, 15-32. doi:10.1007/s10551-009-0136-7.

Beekun, R. I., Stedham, Y., \& Yamamura, J. H. (2003) Business ethics in Brazil and the U.S.: A comparative investigation. Journal of Business Ethics, 42, 267-279.doi:10.1023/A:1022200702149

Beenen, G., \& Pinto, J. (2009) Resisting Organizational-level corruption: an interview with Sherron Watkins. Academy of Management Learning \& Education, 8, 275-289. doi:10.5465/AMLE.2009.41788851

Behrens, A. (2015). The impact of culture on the efficacy and fairness of whistleblowing: A contrast between Brazil and United States. Thunderbird International Business Review, 57, 359-365. doi: 10.1002/tie.21714

Berenbeim, R. E. (2010). Utilizing HR and Ethics and Compliance collaboration to promote and ethical culture. Employment Relations Today, 37, 17-26. doi:10.1002/ert.20281. 
Berenbeim, R. E., \& Walker, R. (2008). Survey points to both risks and benefits posed by third-party ethics program requirements. Employment Relations Today, 35, 15-23. doi: 10.1002/ert.20197.

Bertrand, O., \& Lumineau, F (2016). Partners in crime: The effects of diversity on the longevity of cartels. Academy of Management Journal, 59, 983-1008. doi:10.5465/amj.2013.1209

Bizzi, L. (2013). The dark side of structure holes: A multilevel investigation. Journal of Management, 39, 1554-1578. doi: 10.1177/0149206312471385

Blau, P.M. (1986). Exchange and power in social life. News Brunswick: Transaction Publishers.

Bon, A. C., Volkema, R., \& Silva, J. F. (2017). Ethical decision-making: The role of self-monitoring, future orientation and social network. Brazilian Administration Review, 14, 1-19. doi: 10.1590/18077692 bar2017160091.

Borini, F. M., \& Grisi, F. C. (2009). A corrupção no ambiente de negócios: Survey com as micro e pequenas empresas da cidade de São Paulo, Revista de Administração São Paulo (RAUSP), 44, 102117. doi: $10.5700 /$ rausp1073.

Bourdieu, P. (1986). The forms of capital, In: Richardson, J. G. (Ed.), Handbook of Theory and Research for the sociology of Education, New York: Greenwood Press.

Brass, D. J., Butterfield, K. D., \& Skaggs, B. C. (1998). Relationships and unethical behavior: A social network perspective. Academy of Management Review, 23, 14-31. doi: 10.2307/259097.

Burt, R. S. (1992). Structural holes: The social structure of competition. Cambridge, MA: Harvard University Press

Burt, R. S. (1998). The gender of social capital. Rationality and Society, 10, 5-46. doi: $10.1177 / 104346398010001001$

Burt, R. S. (2005). Brokerage and closure. An introduction to social capital. New York: Oxford University Press.

Chang, J., \& Lai, C. (2002). Is efficiency wage efficient? The social norm and organizational corruption. Scandinavian Journal of Economics, 104, 27-47. doi:10.1111/1467-9442.00270

Chelminski, P., \& Coulter, R.A. (2007). The effects of cultural individualism and self-confidence on propensity to voice: From theory to measurement to practice. Journal of International Marketing, 15, 94-118. doi: 10.1509/jimk.15.4.94

Chen, Y., Yasar, M., \& Rejesus, R. M. (2008). Factors influencing the incidence of bribery payouts by firms: A cross-country analysis. Journal of Business Ethics, 77, 231-244. doi:10.1007/s10551-0069346-4

Coffey, F. (2014). The role and effectiveness of Ethics and Compliance practitioners. London: Institute of Business Ethics.

Cohen, J., Ding, Y., Lesage, C., \& Stolowy, H. Corporate fraud and manager's behavior: evidence from the Press. Journal of Business Ethics, 95, 271-315, 2010. doi: 10.1007/s10551-011-0857-2

Colle, S., \& Werhane, P. H. (2008). Moral motivation across ethical theories. What can we learn for designing corporate ethics programs? Journal of Business Ethics, 81, 751-764, doi: 10.1007/s10551007-9545-7

Coleman, J. S. (1990). Foundations of Social Theory. 1st Edition. MA: Harvard University Press.

De Maria, W. (2006). Brother secret, sister silence: sibling conspiracies against managerial integrity. Journal of Business Ethics, 65, 219-234. doi: 10.1007/s10551-005-4710-3

Ferreira, M. P., Carreira, H. C., Li, D., \& Serra, F. R. (2016). The Moderating Effect of Home Country Corruption on the Host Country's Ability to Attract FDI. Brazilian Business Review, 14, 93-11. doi: 10.15728/bbr.2016.13.4.5 
Flynn, F. J., \& Wiltermuth, S. S. (2010). Who's with me? False consensus, brokerage and ethical decision making in organizations. Academy of Management Joumal, 53, 1074-1089. doi:10.5465/AMJ.2010.54533202

Fogel, K. (2006). Oligarchic family control, social economic outcomes, and the quality of government. Journal of International Business Studies, 37, 603-622. doi: 10.1057/palgrave.jibs.8400213

Galang, R. M. N. (2012). Victim or victimizer: firm responses to government corruption. Journal of Management Studies, 49, 429-462. doi: 10.1111/j.1467-6486.2010.00989.x

George, G. S, Howard-Grenville, J., Joshi, A., \& Tihanyi, L. (2016). Understanding and tackling societal Grand Challenges through management research. Academy of Management Journal, 59, 1880-1895. doi: $10.5465 / \mathrm{amj} .2016 .4007$

Getz, K.A., \& Volkema, R. J. (2001). Culture perceived corruption and economics: a model of predictors and outcomes. Business and Society, 40,7-30, doi: 10.1177/000765030104000103

Granovetter, M. S. (1985). Economic action and social structure: the problem of social embeddedness. American Journal of Sociology, 31, 481-580.

Greve, H. R., Palmer, D., \& Pozner, J. (2010). Organizations gone wild: The causes, processes and consequences of organizational misconduct. The Academy of Management Annals, 4, 53-107. doi: $10.1080 / 19416521003654186$

Gulati, R. (1998). Alliances and Networks. Strategic Management Journal, 19, 293-317. doi: 10.1002/(SICI)1097-0266(199804)19:4<293::AID-SMJ982>3.0.CO;2-M

Gulati, R., Nohria, Z., \& Zaheer, A. (2000). Strategic Networks. Strategic Management Journal,21, 203-215.

Hauser, C. (2018). Fighting against corruption: Does anti-corruption training makes any difference? Journal of Business Ethics, 159, 281-299. doi: 10.1007/s10551-018-3808-3

Hoffman W. H. (2007). Strategies for managing a portfolio of alliances. Strategic Management Journal, 28, 827-856. doi: 10.1002/smj.607

Hoffman, W. M. (2010). Repositioning the Corporate Ethics Officer. Business Ethics Quarterly,20, 744-745.

Hoffman, W. M., Neill, J. D., \& Stovall, O. S. (2008). An investigation of ethics officer independence. Journal of Business Ethics, 78, 87-95. doi: 10.1007/s10551-006-9312-1

Hofstede, G. (1980). Culture's Consequence. Beverly Hills, CA: Sage.

Huang, F., \& Rice, J. (2012). Firms networking and bribery in China: Assessing some potential negative consequences of Firms openness. Journal of Business Ethics, 107, 533-545. doi: 10.1007/s10551-011$1062-z$

Husted, B. W. (2002). Culture and international anti-corruption agreements in Latin America. Journal of Business Ethics, 37, 413-422. doi: 10.1023/A:1015248921716

Ibarra, H. (1997). Paving an alternative route: gender differences in managerial networks. Social Psychology Quarterly, 60, 91-102. doi: 10.2307/2787014

Jackson, R. W., Wood, C. M., \& Zboja, J. J. (2013). The dissolution of ethical decision-making in organizations: a comprehensive review and model. Journal of Business Ethics, 116, 223-250. doi: $10.1007 / \mathrm{s} 10551-012-1459-3$

Jones, T. M. (1991). Ethical decision-making by individuals in organizations: An issue-contingent model. Academy of Management Review, 16(2), 366-395. doi: 10.2307/258867

Judge, W. Q., McNatt, D. B., \& Xu, W. (2011). The antecedents and effects of national corruption: A meta-analysis. Journal of World Business, 46, 93-103. doi: 10.1016/j.jwb.2010.05.021 
Kaptein, M. (2015). The effectiveness of ethics program: the role of scope, composition and sequence. Journal of Business Ethics, 132, 415-431. doi: 10.1007/s10551-014-2296-3

Kilduff, M., \& Krackhardt, D. (2008). Interpersonal Networks in Organizations. Cognition, Personality, Dynamics and Culture. New York: Cambridge University Press.

Kish-Gephardt, J. J., Harrison, D. A., \& Trevino, L. K. (2010). Bad apples, bad cases, bad barrels: analytic evidence about sources of unethical decision at work. Journal of Applied Psychology, 95, 1-31. doi $10.1037 / \mathrm{a} 0017103$

Li, H., Xu, L. C., \& Zou, H. (2000). Corruption, income distribution and growth. Economics and Politics, 12. 155-182. doi: 10.1111/1468-0343.00073

Ledenova, A. (1998). Russia's economy of favours: Blat, networking and informal exchange. Cambridge: Cambridge University Press.

Lin, N. (2001). A Theory of social structure and action. New York: Cambridge University Press.

Lin, N., \& Erickson, B. H. (2008). Social Capital, an International Research Program. Oxford: Oxford University Press.

Lizardo, O. (2009). How cultural tastes shape personal networks. American Sociological Review, 71, 778-807. doi: $10.1177 / 000312240607100504$

Lopes Junior, E. P., Câmara, S. F., Rocha, L. G., \& Brasil, A. (2018). Influence of corruption on stateowned enterprise expenditures. Brazilian Journal of Public Administration, 52, 695-71. doi:10.1590/0034-7612173631

López, J. A. P., \& Santos, J. M. S. (2014). Does Corruption have social roots? The role of culture and social capital. Journal of Business Ethics, 122, 697-708. doi:10.1007/s10551-013-1789-9

Martin, K. D., Cullen, J. B., Johnson, J. L., \& Parbotheeah, K. P. (2007). Deciding to bribe: a cross-level analysis of firm and home country influences on bribery activity. Academy of Management Journal, 50, 1401-1422. doi:10.5465/AMJ.2007.28179462

Mauro, P. (1995). Corruption and growth. Quarterly Journal of Economies, 110, 681-712, doi: $10.2307 / 2946696$

Mauro, P. (1998). Corruption and the composition of government expenditure. Journal of Public Economies, 69, 263-279. doi 10.106/S0047-2727(98)0025-5

McCarthy, D. J., \& Puffer, S. M. (2008). Interpreting the ethicality of corporate governance decisions in Russia: utilizing integrative social contracts theory to evaluate the relevance of agency theory norms, Academy of Management Review, 33, 11-31. doi 10.5465/AMR.2008.27745006

McCarthy, D. J., Puffer, S. M., Dunlap, D. R., \& Jaeger, A. M. (2012). A stakeholder approach to the ethicality of BRIC-firm manager's use of favors. Journal of Business Ethics, 109, 27-38. doi. 10.1007/s10551-012-1377-4

Melé, D. (2009). The practice of networking: an ethical approach. Journal of Business Ethics, 90, 487-503. doi:10.1007/s10551-010-0602-2

Melé, D., Debeljuh, P., Arruda, M. (2006). Corporate ethical policies in large corporations in Argentina, Brazil and Spain. Journal of Business Ethics, 63, 21-38. doi:10.1007/s10551-005-7100-y

Melo, F. L. N. B., Sampaio, L. M. B. \& Oliveira, R. L. (2015). Corrupção Burocrática e Empreendedorismo: uma análise empírica dos estados brasileiros. Revista de Administração Contemporânea, 19, 374-397, doi: 10.1590/1982-7849rac20151611 
Miari, C. R., Mesquita, J. M. C., \& Pardini, D. J. (2015). Market efficiency and organizational corruption: Study on the impact on shareholder value. Brazilian Business Review, Special Issue, 1-23. doi:10.15728/bbrconf.2015.1

Milliken, F. J., Morrison, E. W., \& Hewlin, P. F. (2003). An exploratory study of employee silence: issues that employees don't communicate upward and why. Journal of Management Studies, 40, 1453-1476. doi: 10.1111/1467-6486.00387

Moliterno, T. P., \& Mahony, D. M. (2011). Network theory of organization: a multilevel approach. Journal of Management, 37, 443-467. doi: 10.1177/0149206310371692

Morselli, C., \& Roy, J. (2008). Brokerage qualifications in ringing operations. Criminology, 46, 71-98. doi: $10.1111 /$ j.1745-9125.2008.00103.x

Muehlheusser, G., \& Roider, A. (2008). Black Sheep and walls of silence. Journal of Economic Behavior \& Organization, 65, 387-408. doi:10.1016/j/jebo.2005.11.004

Nicholls-Nixon, C. L., Castilla, J. A. D., \& Garcia, J. S. (2011). Latin America management research: Review, synthesis and extension. Journal of Management, 37, 1178-1227. doi: $10.1177 / 0149206311403151$

Nielsen, R. P. (2003). Corruption networks and implications for ethical corruption reform. Journal of Business Ethics, 42, 125-149. doi: 10.1023/A:1021969204875

O'Fallon, M. J., \& Butterfield, K. D. (2005). A review of the empirical ethical decision-making literature: 1996-2003. Journal of Business Ethics, 59, 375-413. doi: 10.1007/s10551-005-2929-7

Padula, A. J. A., \& Albuquerque, P. H. M. (2018). Corrupção Governamental no Mercado de Capitais: um estudo acerca da Operação Lava Jato. Revista de Administração de Empresas, 58, 405-41. doi:10.1590/S0034-759020180406

Pendse, S. G. (2012). Ethical hazard: A motive, mean and opportunity approach to curbing corporate unethical behavior. Journal of Business Ethics, 107, 265-279. doi:10.1007/s10551-011-1037-0

Pinto, J., Leana, C. R., \& Pil, F. K. (2008). Corrupt organizations or organizations of corrupt individuals? Two types of organization-level corruption. Academy of Management Review, 33, 685709. doi: 10.5465/AMR.2008.32465726

Poldony, J. M., \& Baron, J. N. (1997). Resources and relationships: social network and mobility in the workplace. American Sociological Review, 62, 673-693.

Putman, R. D. (2001). Social Capital. Measurement and Consequences. Canadian Journal of Policy Research, 2, 41-51. doi:10.1023/A:1004826703499.

Rabl, T., \& Kuhlmann, T.M. (2008). Understanding corruption in organizations: development and empirical assessment of an action model. Journal of Business Ethics, 82, 477- 495, doi: 10.1007/s10551-008-9898-6

Ribeiro, H. V., Alves, L. G. A., Martins, A. F., \& Lenzi, E. K. (2018). The dynamics of political networks. Journal of Complex Networks, 6, 989-1003. doi: 10.1093/comnet/cny002

Rodriguez, P., Uhlenbruck, K., \& Eden, L. (2005). Government corruption and the entry strategies of multinationals. Academy of Management Review, 30, 383-396. doi:10.5465/AMR.2005.16387894

Sampaio, D. B. D. (2015). Speak now or forever hold your peace? An essay on whistleblowing and its interface with the Brazilian culture. Brazilian Administration Review, 10, 370-388. doi: 10.1590/S180776922013000400002

Santos, R. A., Guevara, A. J. H., \& Amorim, M. C. S. (2013). Corrupção nas organizações privadas: análise da percepção moral segundo gênero, idade e grau de instrução. Revista de Administração São Paulo, 48, 53-66. doi: 10.5700/rausp1073 
Seibert, S. E., Kraimer, M. L., \& Liden, R. C. (2001). A social capital theory of career success. Academy of Management Journal, 44, 219-237. doi: 10.2307/3069452

Sodré, A. C. A., \& Alves, M. F. C. (2010). The relationship between amendments to the Federal Budget Law and municipal corruption in Brazil: evidence from reports of the Brazilian Internal Audit Agency. Revista de Aministração Contemporânea, 14, 414-433. doi: 10.1590/S141565552010000300003

Spencer, J., \& Gomez, C. (2011) MNEs and corruption: the impact of national institutions and subsidiary strategy. Strategic Management Journal, 32, 280-300. doi:10.1002/smj.874

Su, C., Sirgy, M. J., Littlefield, J. E. (2003). Is Guanxi orientation bad, ethically speaking? A study of Chinese enterprises. Journal of Business Ethics, 44, 303-312. doi:10.1023/A:1023696619286

Su, C., \& Littlefield, J. E. (2001). Entering Guanxi: a business ethical dilemma in Mainland China? Journal of Business Ethics, 33, 199-201. doi:10.1023/A:1017570803846

Svensson, J. (2003). Who must pay bribes and how much? Evidence form a cross-section of firms. The Quarterly Journal of Economics, 118, 207-230. doi:10.1162/0033553036053180

Tihany, L.; Graffin, S.; \& George, G. (2014). Rethinking Governance in Management Research. Academy of Management Journal, 57, 1535-1543. doi: 10.5465/amj.2014.4006

Torres, C. V., Alfinito, S., Galvão, C. A. S. P., \& Tse, C. Y. T. (2015). Brazilian jeitinho versus Chinese guanxi: Investigating their informal influence on international business. Revista de Administração Mackensie, 16, 77-99. doi:10.1590/1678-69712015

Torres, F. (2014). Maioria das Companhias admite possível suborno. Valor Econômico, São Paulo, 18 de fevereiro de 2014. Empresas, p. B2.

Tuliao, K. V., Chen, C. (2017). CEO duality and bribery: The roles of gender and national culture, Management Decision, 55, 218-231. doi:10.1108/MD-12-2015-0608

Umphress, E. E., \& Bingham, J. B. (2011). When employees do bad things for good reasons: examining unethical pro-organizational behavior. Organization Science, 22, 621-640. doi:10.1287/orsc.1100.0559

Van Meter, K.M. (2001). Terrorists /Liberators: researching and dealing with adversary social networks. Connections, 24, 66-78.

Verhezen, P. (2010). Giving Voice in a Culture of Silence. From a Culture of Compliance to a Culture of Integrity. Journal of Business Ethics, 96, p. 187-206. doi:10.1007/s10551-010-0458-5

Weaver, G. R., Trevino, L. K., \& Cochran, P. L. (1999). Corporate ethics programs as control systems: Management and environmental influences. Academy of Management Journal, 42, 41-57. doi: $10.2307 / 256873$

Weber, J.; Wasieleski, D. M. (2013). Corporate Ethics and Compliance Programs. A Report, Analysis and Critique. Journal of Business Ethics,112, 609-626. doi:10.1007/s10551-012-1561-6

Wiltermuth, S. S. (2011). Cheating more when the spoils are split. Organizational Behavior and Human Decision Process, 115, 157-168, doi: 10.1016/j.obhdp.2010.10.00 